\title{
Influence of the Local Structure on the Photocatalytic Properties of Zinc Spinel Ferrite Nanoparticles
}

\author{
Luciana B. Biazati, ${ }^{\oplus a}$ Lucas Lorenzini, ${ }^{\oplus a}$ Sandra A. D. Ferreira, ${ }^{\oplus a}$ Arilza O. Porto, ${ }^{\odot * b}$ \\ Eustáquio V. R. de Castro, ${ }^{\circledR a}$ José D. Fabris, ${ }^{\oplus b}$ Marcos B. J. G. de Freitas ${ }^{\circledR a}$ and \\ Maria de Fátima F. Lelis ${ }^{\circledR} * a$ \\ ${ }^{a}$ Departamento de Química, CCE, Universidade Federal do Espírito Santo, Campus Goiabeiras,
29075-910 Vitória-ES, Brazil \\ ${ }^{b}$ Departamento de Química, ICEx, Universidade Federal de Minas Gerais, Campus Pampulha, \\ 31270-901 Belo Horizonte-MG, Brazil
}

\begin{abstract}
The correlation between iron distribution in octahedral or tetrahedral sites in synthetic magnetite and zinc spinel ferrites and their catalytic properties were investigated in this work. The zinc-doped nanomagnetites were prepared by co-precipitation method and annealed at $420{ }^{\circ} \mathrm{C}$. $\mathrm{X}$-ray diffraction, UV-Vis, X-ray absorption and ${ }^{57} \mathrm{Fe}$ Mössbauer spectroscopies were used to identify iron sites. The obtained results showed that $\mathrm{Zn}^{\mathrm{II}}$ replaces the relatively smaller $\mathrm{Fe}^{\mathrm{III}}$ cation in the tetrahedral sites, increasing the cubic lattice dimension, and this replacement remarkably enhances the catalytic effectiveness of the $\mathrm{Zn}$-spinel ferrite towards the indigo carmine degradation compared to undoped magnetite. The indigo carmine degradation experiments were carried out using photo-Fenton method in which $50 \mathrm{~mL}$ of indigo carmine dye aqueous solutions $\left(20 \mathrm{mg} \mathrm{L}^{-1}\right.$, pH 3.0), $20 \mathrm{mg} \mathrm{Zn}_{\mathrm{x}} \mathrm{Fe}_{(3-\mathrm{x})} \mathrm{O}_{4}$, and $2.0 \mathrm{~mL} \mathrm{H}_{2} \mathrm{O}_{2}$ (aqueous solution at $0.028 \mathrm{~mol} \mathrm{~L}^{-1}$ ) were placed under UV light at $25{ }^{\circ} \mathrm{C}$. Under these experimental conditions the degradation rate of indigo carmine was superior to $98 \%$.
\end{abstract}

Keywords: ferrites, XANES, EXAFS, Mössbauer spectroscopy, Fenton process, indigo carmine

\section{Introduction}

Ferrite spinels are magnetic compounds containing iron, for which the general chemical stoichiometry corresponds to $\left(\mathrm{M}_{2}^{\mathrm{k}} \mathrm{O}_{\mathrm{k}}^{-\mathrm{II}}\right)_{\frac{\mathrm{m}}{2}}\left(\mathrm{Fe}_{2}^{\mathrm{III}} \mathrm{O}_{3}^{-\mathrm{II}}\right)_{\mathrm{n}}$, where $\mathrm{M}$ is a metal cation of valence $\mathrm{k}$ occupying tetrahedral sites; $\mathrm{m}$ and $\mathrm{n}$ are integer numbers. ${ }^{1}$ For magnetite, $\mathrm{M}=\mathrm{Fe} ; \mathrm{k}=2 ; \mathrm{m}=1$ and $\mathrm{n}=1$, and the ideal formula is $\left[\mathrm{Fe}^{\mathrm{III}}\right]\left\{\mathrm{Fe}^{\mathrm{IIII}} \mid \mathrm{Fe}^{\mathrm{II}}\right\} \mathrm{O}_{4}$, where $\mathrm{Fe}^{\mathrm{III}}$ and $\mathrm{Fe}^{\mathrm{II}}$ occupy tetrahedral and octahedral coordination sites, respectively.

Ferrites are widely researched materials due to their broad range of technological applications in electronic devices, ${ }^{2}$ such as high-speed digital tapes, recording discs, rod antennas, and humidity sensors, ${ }^{3-6}$ gas sensor in environmental monitoring,,${ }^{7.8}$ permanent magnets, ${ }^{9}$ catalytic reactions, ${ }^{10-12}$ and as absorbent materials for environmental applications. ${ }^{13}$ Their properties are strongly influenced by

*e-mail: aop@ufmg.br; mfflelis@yahoo.com.br

Editor handled this article: Jaísa Fernandes Soares particle size distributions, particle agglomeration degree and morphologies. ${ }^{14}$ Those microstructural parameters can be well controlled during the synthesis. Doping processes of ferrites nanocrystals using different metals, such as zinc, ${ }^{15,16}$ nickel, ${ }^{17}$ copper, ${ }^{11}$ manganese ${ }^{18}$ and cobalt ${ }^{19}$ are commonly used to improve their electric, catalytic, or magnetic properties. ${ }^{17,18}$

Several methods using chemical synthesis of zinc ferrite nanoparticles have been reported such as coprecipitation, ${ }^{11,17,18,20}$ hydrothermal, ${ }^{14}$ sol-gel, ${ }^{19}$ and polymeric precursors. ${ }^{21}$ The properties of these materials are strongly influenced by the chemical composition and microstructure which are significantly dependent on the chemical route used for their synthesis. The most common method used to obtain these doped ferrites is co-precipitation which involves the use of metal salts at different molar ratio (Fe:Metal) in a basic environment $(\mathrm{pH}>8){ }^{11,17,18}$

In this work, zinc-doped ferrites were prepared and those compounds are spinel systems which present $\mathrm{AB}_{2} \mathrm{O}_{4}$-type structures, where $8 \mathrm{Zn}^{\mathrm{II}}$ and $16 \mathrm{Fe}^{\mathrm{III}}$ ions occupy tetrahedral and octahedral sites, respectively, in 
a crystallographic face-centered cubic unit cell. ${ }^{16,22}$ The electric and magnetic properties of these materials are also highly influenced by their cation occupation in tetrahedral and octahedral sites. Due to the relatively small energy difference among $\mathrm{Zn}^{\mathrm{II}}$ ions in $\mathrm{T}$ and $\mathrm{M}$ sites, ${ }^{9,11}$ cation redistribution is strongly influenced by the annealing temperature and cooling rate used during the synthesis. ${ }^{22}$ $\mathrm{Zn}_{\mathrm{x}} \mathrm{Fe}_{(3-\mathrm{x})} \mathrm{O}_{4}$ is an important member of the spinel ferrite family and an efficient photocatalyst mainly due to its ability to absorb visible light..$^{23-25}$ The photochemical stability of $\mathrm{Zn}_{\mathrm{x}} \mathrm{Fe}_{(3-\mathrm{x})} \mathrm{O}_{4}$ remarkably promotes an efficient conversion of $\mathrm{H}_{2} \mathrm{O}_{2}$ into highly reactive $\mathrm{HO} \bullet$ radical, addressing its particular interest on the oxidative photocatalytic degradation of organic substrates. ${ }^{11,12}$ Some reported data on the use of $\mathrm{Zn}_{\mathrm{x}} \mathrm{Fe}_{(3-\mathrm{x})} \mathrm{O}_{4}$ nanoparticles also showed their hydrophobic and hydrophilic anticancer behavior through local drug delivering systems, ${ }^{26-29}$ another very interesting application of these materials.

In this work the synthesis using coprecipitation method and the characterization of zinc-doped ferrite samples is described as well as photocatalysis tests under UV light The crystallographic and hyperfine structures, along with the cation distribution of the undoped and $\mathrm{Zn}$-doped samples, were assessed by UV-Vis, X-ray absorption (XAS) and ${ }^{57} \mathrm{Fe}$ Mössbauer spectroscopies and X-ray diffraction (XRD). XAS is an ideal technique to investigate the local structure around different cations due to its high chemical selectivity and sensitivity. The influence of the chemical structure on the catalytic efficiency of these zinc ferrite nanocrystals towards the degradation of the indigo carmine dye was also reported in this work which undoubtedly allows a better understanding of the main chemical mechanisms involved in dye degradation process.

\section{Experimental}

\section{Synthesis and characterization}

Doped ferrites were synthetized by co-precipitation of $\mathrm{Zn}^{\mathrm{II}}$ and $\mathrm{Fe}^{\mathrm{III}}$ chlorides in aqueous solutions, at room temperature, through addition of ammonium hydroxide. All chemicals used, $\mathrm{FeCl}_{3} \cdot 6 \mathrm{H}_{2} \mathrm{O}, \mathrm{ZnCl}_{2}, \mathrm{NH}_{4} \mathrm{OH}$, $\mathrm{CH}_{3} \mathrm{COONH}_{4}, \mathrm{HCl}$ and $\mathrm{K}_{2} \mathrm{Cr}_{2} \mathrm{O}_{7}$ were purchased from Vetec (New Química, Vitória-ES, Brazil). The obtained solids were washed with ammonium acetate, dried, and decomposed under $\mathrm{N}_{2}$ atmosphere at $420{ }^{\circ} \mathrm{C}$ for $2 \mathrm{~h} .{ }^{30}$ A sample of pure magnetite was prepared and used as reference. Total iron was then quantified by using the standard dichromatometric method $;{ }^{31}$ in this analysis it was possible to quantify $\mathrm{Fe}^{\mathrm{II}}$. In this method the samples were dissolved in $\mathrm{HCl}$ aqueous solution under $\mathrm{CO}_{2}$ atmosphere and titrated with $\mathrm{K}_{2} \mathrm{Cr}_{2} \mathrm{O}_{7}$. Zn content was determined by inductively coupled plasma optical emission spectrometry (ICP-OES) on a PerkinElmer Optima 7000DV.

XRD data were acquired on a Rigaku Geigerflex diffractometer equipped with a Co tube (Ko radiation, $\lambda=0.17092 \mathrm{~nm}$ ) and a graphite monochromator using a scanning rate of $1^{\circ} 2 \theta \mathrm{min}^{-1}$ and a dwell time of $5 \mathrm{~s}$ per step. Room-temperature ${ }^{57} \mathrm{Fe}$ Mössbauer spectra were recorded on a conventional transmission constant acceleration spectrometer using a ${ }^{57} \mathrm{Co} / \mathrm{Rh}$ source. $\alpha \mathrm{Fe}$ foil was used to calibrate the Doppler velocity and isomer shift. All spectra were numerically fitted using the least-squares computer program NORMOS-90. ${ }^{32}$ Samples were mixed with sugar in order to obtain an averaged Fe density of about $10 \mathrm{mg} \mathrm{cm}^{-2}$. A $13 \mathrm{~mm}$ diameter acrylic disc was used as sample holder.

XAS measurements were performed using the DB04-XAFS1 beamline at the National Synchrotron Light Laboratory (LNLS), Campinas, Brazil. All spectra were collected at the $\mathrm{Zn} \mathrm{K}$-edge $(9659 \mathrm{eV})$ for $\mathrm{ZnFe}_{2} \mathrm{O}_{4}$ and $\mathrm{ZnO}$ (standard) in transmission mode using a $\mathrm{Si}(111)$ channelcut monochromator, previously calibrated using $7.5 \mu \mathrm{m} \mathrm{Zn}$ foil. X-ray absorption near edge structure (XANES) spectra were recorded from 9600 to $9700 \mathrm{eV}$ at $0.5 \mathrm{eV}$ steps with $5 \mathrm{~s}$ counting time. Extended X-ray absorption fine structure (EXAFS) data were collected from 9700 to $10700 \mathrm{eV}$ at $3.0 \mathrm{eV}$ steps and with $5 \mathrm{~s}$ counting time. EXAFS spectra were numerically treated using the WinXAS algorithm. ${ }^{33}$ XANES data were background-corrected by using a polynomial fit in the pre-edge region and normalized in the 9600-9655 eV energy range for $\mathrm{Zn}$ samples. The edge position was determined as the zero of the second derivative of experimental spectra. Atomic absorption data were fitted by a cubic spline function in the $k^{3}$ space. EXAFS signals, $k^{3} \cdot \chi(k)$, were Fourier-transformed using a Bessel window to obtain the radial distribution function (RDF). As we were interested only in the first coordination shell, which gives information about $\mathrm{Zn}^{\mathrm{II}}$ sites, we applied a Fourier back-transformation only to the first RDF peak and fitted the obtained $\chi(k)$ functions by the least-squares procedure, using experimental phases and amplitudes extracted from a standard compound, $\mathrm{ZnO}$, which contains $4 \mathrm{Zn}-\mathrm{O}$ bonds at $1.98 \AA$.

\section{Photocatalytic tests}

The photocatalytic activity of $\mathrm{Zn}_{\mathrm{x}} \mathrm{Fe}_{(3-\mathrm{x})} \mathrm{O}_{4}$ was assessed by degradation of indigo carmine dye solutions via oxidation processes in the presence of $\mathrm{H}_{2} \mathrm{O}_{2}$ and UV light or direct photolysis. $20 \mathrm{mg}$ of $\mathrm{Zn}_{\mathrm{x}} \mathrm{Fe}_{(3-\mathrm{x})} \mathrm{O}_{4}$ and $2.0 \mathrm{~mL}$ of $\mathrm{H}_{2} \mathrm{O}_{2}$ aqueous solution $\left(0.028 \mathrm{~mol} \mathrm{~L}^{-1}\right)$ were mixed and then 
added to $50 \mathrm{~mL}$ of indigo carmine dye aqueous solution (20 mg L $\left.{ }^{-1}, \mathrm{pH} 3.0\right)$ at room temperature $\left(25^{\circ} \mathrm{C}\right)$. These reaction systems were kept at a distance of $15 \mathrm{~cm}$ from a UV lamp (Philips, $80 \mathrm{~W}$ ). Aliquots were collected at equal time intervals and centrifuged and then their absorbance values were determined as the peak maximum at $610 \mathrm{~nm}$ using a Hach DR 5000 UV-Vis spectrophotometer. Dye removal efficiency was then calculated using the concentration values. Photolysis and adsorption tests of indigo carmine in the presence of $\mathrm{Zn}_{\mathrm{x}} \mathrm{Fe}_{(3-\mathrm{x})} \mathrm{O}_{4}$ were also carried out for comparison with the results of oxidation reactions.

\section{Results and Discussion}

The chemical formulae obtained through chemical analysis, Table 1, showed that both samples present some degree of oxidation which was confirmed by the presence of cation vacancies. XRD patterns (Figure 1) display reflections that are assigned to the cubic phase of $\mathrm{ZnFe}_{2} \mathrm{O}_{4}$ (franklinite, JCPDS card number 22-1012). ${ }^{34}$ Lattice parameters (Table 1) were calculated through the analysis of (220), (311) and (440) reflections using UnitCell software. ${ }^{35} \mathrm{ZnFe}_{2} \mathrm{O}_{4}$ spinel cubic phase is reportedly stable at temperatures higher than $360{ }^{\circ} \mathrm{C} .{ }^{35}$ Mean particle size was estimated from the (311) reflection peak breadth, using the Scherrer's equation. ${ }^{36,37}$ The lattice parameter value for this prepared magnetite $\left(\mathrm{Fe}_{3} \mathrm{O}_{4}\right)(a=0.83889(5) \mathrm{nm})$ is well consistent with that of the standard magnetite ( $a=0.8396 \mathrm{~nm}$, JCPDS card No. 19-0629). This result strongly suggests that if ferrous iron oxidation occurred, it did not lead to detectable changes in the crystalline structure of the obtained magnetite. For the zinc doped spinel, $\mathrm{Zn}_{\mathrm{x}} \mathrm{Fe}_{(3-\mathrm{x})} \mathrm{O}_{4}$, the cubic lattice dimension $(a=0.84157(5) \mathrm{nm})$ was found to be higher than that of $\mathrm{Fe}_{3} \mathrm{O}_{4} \cdot{ }^{35,38}$ This cell expansion of $\mathrm{Zn}_{\mathrm{x}} \mathrm{Fe}_{(3-\mathrm{x})} \mathrm{O}_{4}$ was expected as the ionic radii of $\mathrm{Zn}^{\mathrm{II}}$ in tetrahedral and octahedral sites are 60 and $75 \mathrm{pm}$, respectively, which in both cases are higher than the ionic radii of $\mathrm{Fe}^{\mathrm{III}}$ (high spin), which is 49 or $65 \mathrm{pm}$, in tetrahedral and octahedral sites, respectively. ${ }^{37}$ Mean crystallite sizes calculated for $\mathrm{Fe}_{3} \mathrm{O}_{4}$ and $\mathrm{Zn}_{\mathrm{x}} \mathrm{Fe}_{(3-\mathrm{x})} \mathrm{O}_{4}$ were 46 and $22 \mathrm{~nm}$, respectively.

The full width at half maximum (FWHM) values calculated through least squares-fitting of (220), (311)

Table 1. Chemical formula, unit cell parameter $(a)$, and mean crystallite size (D) of samples

\begin{tabular}{lccc}
\hline Sample & Chemical formula & $a / \mathrm{nm}$ & $\mathrm{D} / \mathrm{nm}$ \\
\hline $\mathrm{Fe}_{3} \mathrm{O}_{4}$ & $\mathrm{Fe}_{2.135}^{\mathrm{III}} \mathrm{Fe}_{0.798}^{\mathrm{II}} \otimes_{0.067} \mathrm{O}_{4}^{-\mathrm{II}}$ & $0.83889(5)$ & 46 \\
$\mathrm{Zn}_{\mathrm{x}} \mathrm{Fe}_{(3-\mathrm{x})} \mathrm{O}_{4}$ & $\mathrm{Fe}_{2.000}^{\mathrm{III}} \mathrm{Fe}_{0.544}^{\mathrm{II}} \mathrm{Zn}_{0.457}^{\mathrm{II}} \otimes_{-0.001} \mathrm{O}_{4}^{-\mathrm{II}}$ & $0.84157(5)$ & 22 \\
\hline
\end{tabular}

$\otimes=$ cation vacancy. Numbers in parentheses are uncertainties over the last significant digit of the numerical value, as estimated from the standard deviation obtained from UnitCell code. ${ }^{37}$

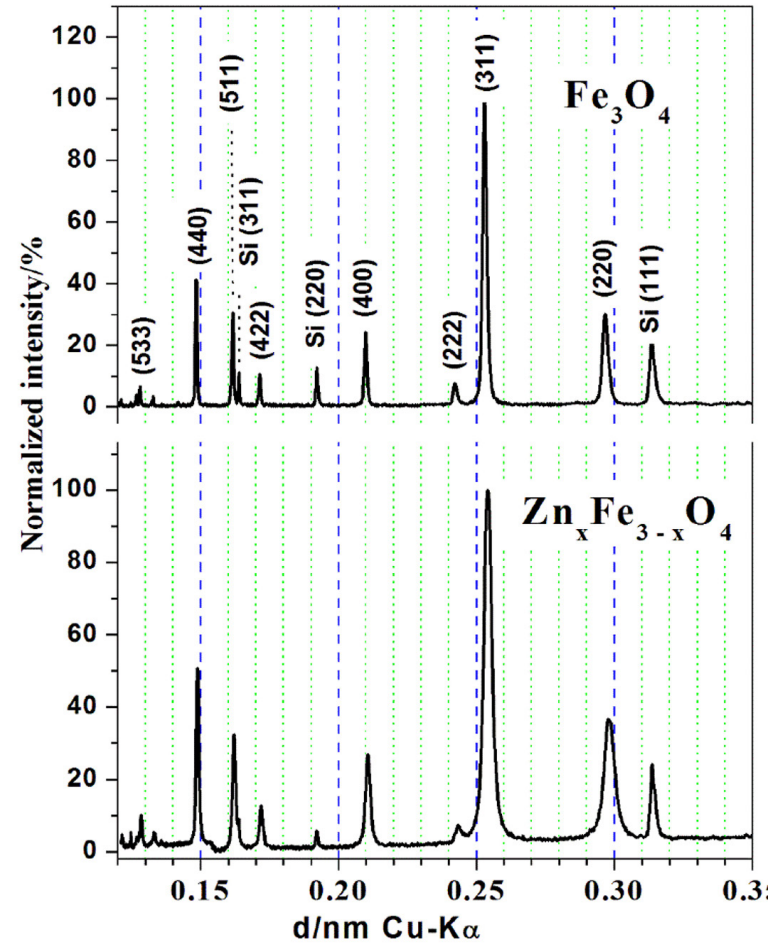

Figure 1. XRD patterns for the $\mathrm{Fe}_{3} \mathrm{O}_{4}$ and $\mathrm{Zn}_{\mathrm{x}} \mathrm{Fe}_{(3-\mathrm{x})} \mathrm{O}_{4}$ samples.

and (440) reflections of $\mathrm{Zn}_{x} \mathrm{Fe}_{(3-\mathrm{x})} \mathrm{O}_{4}$, are approximately greater than twice the values obtained for the $\mathrm{Fe}_{3} \mathrm{O}_{4}$ sample (Table 2).

Table 2. Full width at half maximum (FWHM) of $\mathrm{K}_{\alpha 1}$ Lorentzian components obtained from least squares-fitting the (220), (311) and (440) reflection peaks for the $\mathrm{Zn}_{\mathrm{x}} \mathrm{Fe}_{(3-\mathrm{x})} \mathrm{O}_{4}$ and $\mathrm{Fe}_{3} \mathrm{O}_{4}$ samples

\begin{tabular}{lccc}
\hline Sample & \multicolumn{3}{c}{ FWHM / nm } \\
\hline Diffraction peak & $(220)$ & $(311)$ & $(440)$ \\
\hline $\mathrm{Fe}_{3} \mathrm{O}_{4}$ & $0.00183(2)$ & $0.00128(2)$ & $0.00054(2)$ \\
$\mathrm{Zn}_{\mathrm{x}} \mathrm{Fe}_{(3-\mathrm{x})} \mathrm{O}_{4}$ & $0.00293(3)$ & $0.00257(2)$ & $0.00092(1)$ \\
\hline
\end{tabular}

The room-temperature ${ }^{57} \mathrm{Fe}$ Mössbauer spectrum (Figure 2) of the $\mathrm{Fe}_{3} \mathrm{O}_{4}$ sample showed two well-defined sextets assignable to iron in both tetrahedral and octahedral sites of the spinel structure. Experimental data were fitted by two Lorentzian-shaped sextets for each sub-spectrum, assignable to each $\mathrm{Fe}-\mathrm{O}$ coordination sites, Table 3. These Mössbauer parameters indicate the coexistence of two populations of magnetite in the sample. ${ }^{20}$

In a stoichiometric magnetite, the atomic ratio, $\mathrm{R}_{\text {atomic }}=\frac{\left\{\mathrm{Fe}^{\frac{\mathrm{III}}{\mathrm{II}}}\right\}}{\left[\mathrm{Fe}^{\mathrm{III}}\right]}$, is equal to 2 . To draw the corresponding relative subspectral Mössbauer area (RA) ratio, the 


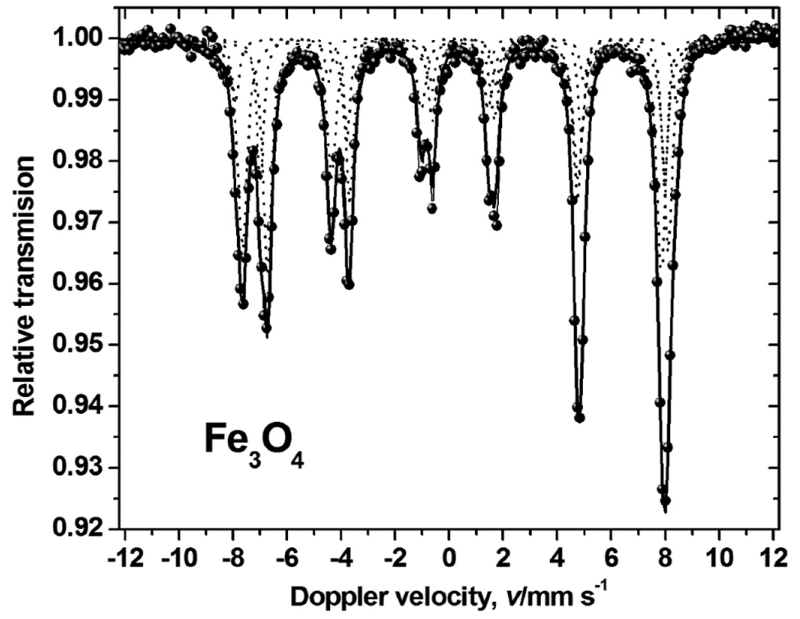

Figure 2. ${ }^{57} \mathrm{Fe}$ Mössbauer spectrum of $\mathrm{Fe}_{3} \mathrm{O}_{4}$ sample at room temperature. Solid lines represent the fit of theoretical Lorentzian functions to the experimental data.

Table 3. ${ }^{57} \mathrm{Fe}$ Mössbauer parameters of $\mathrm{Fe}_{3} \mathrm{O}_{4}$ sample

\begin{tabular}{lcccc}
\hline Site & $\mathrm{B}_{\mathrm{hf}} / \mathrm{T}$ & $\delta /\left(\mathrm{mm} \mathrm{s}^{-1}\right)$ & $2 \varepsilon_{\mathrm{Q}} /\left(\mathrm{mm} \mathrm{s}^{-1}\right)$ & $\mathrm{RA} / \%$ \\
\hline Tetrahedral & $48.9(1)$ & $0.32(1)$ & $0.02(1)$ & 40 \\
RA $=47 \%$ & $50.6(1)$ & $0.36(1)$ & $0.01(2)$ & 7 \\
\hline Octahedral & $45.2(1)$ & $0.65(1)$ & $0.03(1)$ & 40 \\
RA =53\% & $46.4(1)$ & $0.63(1)$ & $0.06(1)$ & 13 \\
\hline
\end{tabular}

$\mathrm{B}_{\mathrm{hf}}$ : hyperfine field; $\delta$ : isomer shift relative to the $\alpha \mathrm{Fe}$ foil; $2 \varepsilon_{\mathrm{Q}}$ : quadrupole shift; RA: relative subspectral area. Numbers in parentheses are uncertainties over the last significant digit of the numerical value, as output by the least squares fitting computer program.

recoilless fraction (f) must be fully taken into consideration. It is reported that the fraction values of $\mathrm{M}$ sites is $6 \%$ below those of $\mathrm{T}$ sites, ${ }^{39,40}$ for a pure and stoichiometric

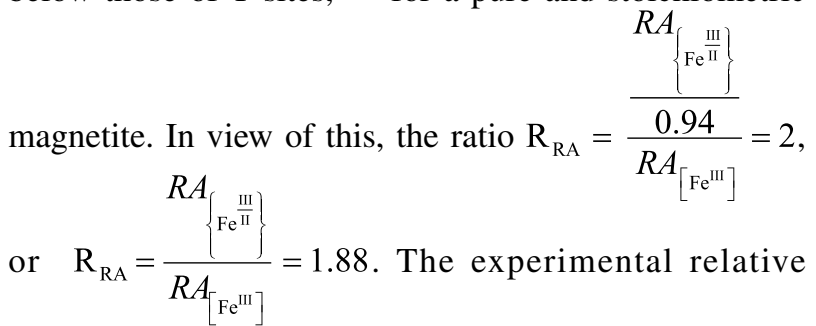
subspectral ratio area, RA, was 1.3 for the $\mathrm{Fe}_{3} \mathrm{O}_{4}$ sample. This result implies that the sample experienced some $\mathrm{Fe}^{\mathrm{II}} \rightarrow \mathrm{Fe}^{\mathrm{III}}$ oxidation, as confirmed by its corresponding chemical composition (Table 1), in the octahedral sites.

The Mössbauer spectrum (Figure 3) of $\mathrm{Zn}_{\mathrm{x}} \mathrm{Fe}_{(3-\mathrm{x})} \mathrm{O}_{4}$ is much more complex compared to the one of stoichiometric frankilinite. The end-member franklinite $\mathrm{ZnFe}_{2} \mathrm{O}_{4}$ itself has a normal spinel structure, with all $\mathrm{Zn}^{\mathrm{II}}$ located in $\mathrm{T}$ sites: its Mössbauer spectrum is composed by only one ferric doublet, with isomer shift relative to the $\alpha \mathrm{Fe}$ and quadrupole splitting values of $\delta=0.348 \mathrm{~mm} \mathrm{~s}^{-1}$ and $2 \varepsilon_{Q}=0.348 \mathrm{~mm} \mathrm{~s}^{-1}$, respectively. ${ }^{23}$ Franklinite is an anti-ferromagnetic oxide, ${ }^{41}$ in which $\mathrm{Zn}$ occupies one tetrahedral site and $\mathrm{Fe}^{\mathrm{III}}$ the octahedral B-sites. ${ }^{42}$ The antiferromagnetism of this compound at room temperature is due to the predominantly negative super-exchange interaction among $\mathrm{Fe}^{\mathrm{III}}$ ions at $\mathrm{M}$ sites. ${ }^{23}$ On the other hand, if a solid solution composed of an intermediate phase between magnetite and franklinite is formed, at least two sextets corresponding to iron in T and $\mathrm{M}$ sites appear, despite the putative preference of $\mathrm{Zn}^{\text {II }}$ for $\mathrm{T}$ sites. Regarding the Mössbauer results (Figure 3) of this $\mathrm{Zn}_{x} \mathrm{Fe}_{(3-\mathrm{x})} \mathrm{O}_{4}$ sample, two broad and asymmetric sextets were observed, indicating partial replacement of $\mathrm{Fe}^{\mathrm{III}}$ by $\mathrm{Zn}^{\mathrm{II}}$, mainly at tetrahedral sites of the spinel structure. The probability profiles of hyperfine field values for both coordination sites are, through this fitting model, linearly correlated with values of isomer shifts displayed in Figure 3.

For $\mathrm{Zn}_{\mathrm{x}} \mathrm{Fe}_{(3-\mathrm{x})} \mathrm{O}_{4}$ the probability profiles of the hyperfine fields, Figure 3, showed a maximum at 43.1 and $47.6 \mathrm{~T}$ for tetrahedral sites and $39.4 ; 42.9$ and $45.7 \mathrm{~T}$ for octahedral sites.
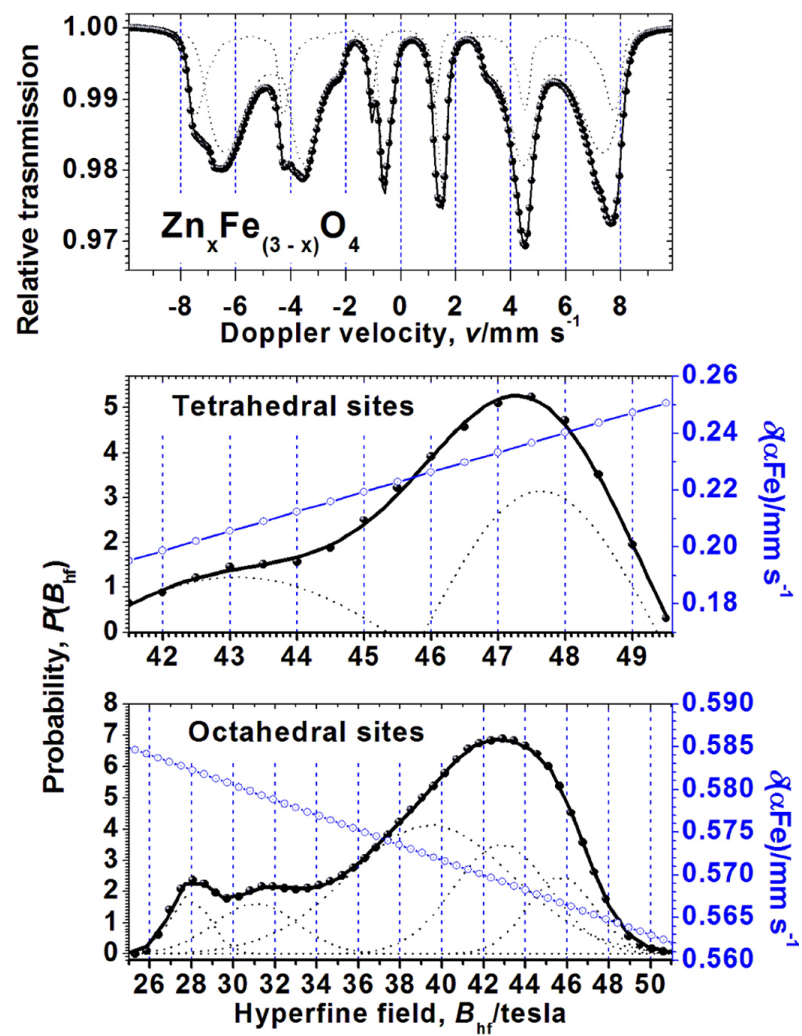

Figure 3. Independent hyperfine field distributions models of ${ }^{57} \mathrm{Fe}$ Mössbauer spectrum of the $\mathrm{Zn}$-doped magnetite sample $\left(\mathrm{Zn}_{\mathrm{x}} \mathrm{Fe}_{(3-x)} \mathrm{O}_{4}\right)$. The probability profiles of the hyperfine fields for tetrahedral (maximum probabilities at 43.1 and $47.6 \mathrm{~T}$ ) and octahedral sites (main peaks of maximum probabilities at $39.4 ; 42.9$ and $45.7 \mathrm{~T}$ ) of the spinel structure are displayed together with the corresponding isomer shift values relative to the $\alpha \mathrm{Fe}$ foil, linearly varying with values of the field.

EXAFS experiments were carried out in $\mathrm{Zn}$-doped magnetite sample in order to determine the $\mathrm{Zn}$ local 
structure. For the raw EXAFS spectrum of the Zn sample (Figure 4a) a good signal-to-noise ratio was achieved. $\chi(k)$ functions weighted by $k^{3}$ were obtained from the Fourier transform of these spectra (Figure 4b) and adjusted using experimental phase shift and amplitude values extracted from $\mathrm{ZnO}$ spectra (standard material). The $k^{3} \cdot \chi(k)$ functions were Fourier transformed over the 2.3-9.2 A range using the Kaiser-Bessel window to obtain the partial RDF functions (Figure 5a) in which the peaks represent shells of atoms surrounding $\mathrm{Zn}$ atoms. As depicted in Figure 5a, the RDF of $\mathrm{ZnO}$ and $\mathrm{Zn}_{\mathrm{x}} \mathrm{Fe}_{(3-\mathrm{x})} \mathrm{O}_{4}$ are relatively similar with the first peak located at $1.51 \AA$. This first peak is associated to $\mathrm{Zn}-\mathrm{O}$

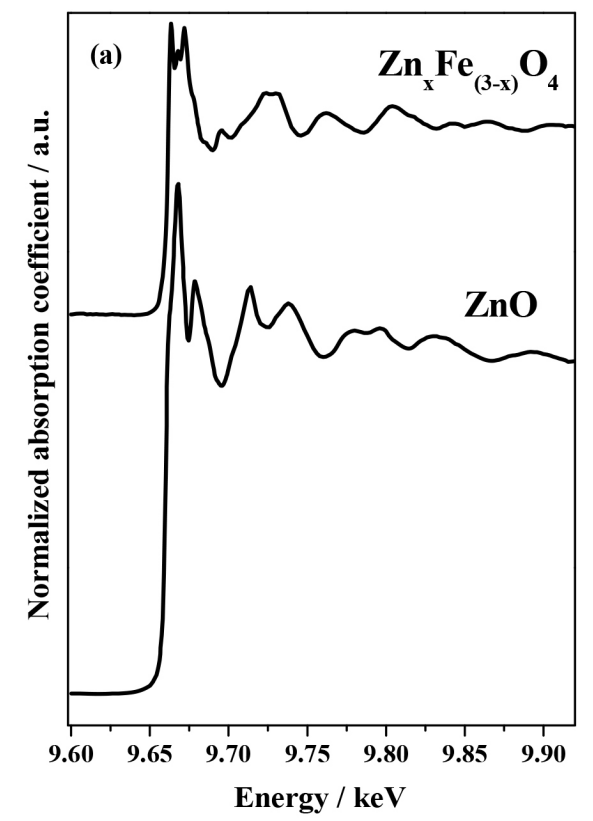

interactions (first coordination shell). The second peak is associated to $\mathrm{Zn}-\mathrm{Zn}$ and $\mathrm{Zn}-\mathrm{Fe}$ interactions. EXAFS parameters of $\mathrm{Zn}_{x} \mathrm{Fe}_{(3-x)} \mathrm{O}_{4}$ (Table 4) were obtained from the fitting of the Fourier back-transformed RDF functions of the first coordination shell using experimental phases and amplitudes extracted from the experimental data obtained from standard $\mathrm{ZnO}$, Figure $5 \mathrm{~b}$. These parameters are in excellent agreement with those found for $\mathrm{Zn}_{\mathrm{x}} \mathrm{Fe}_{(3-\mathrm{x})} \mathrm{O}_{4} \cdot{ }^{34}$ The coordination number obtained for $\mathrm{Zn}-\mathrm{O}$ shell, 3.58, showed that $\mathrm{Zn}$ ions mainly occupy the $\mathrm{T}$ site, in agreement with experimental results of co-precipitation followed by annealing at $420^{\circ} \mathrm{C} .{ }^{16,22}$

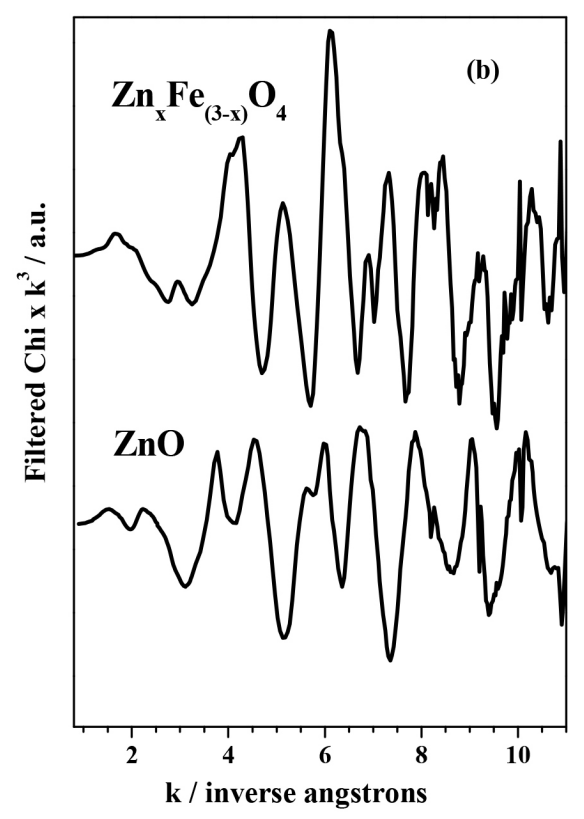

Figure 4. (a) Raw EXAFS spectra and (b) $k^{3}$-weighted $\chi(k)$ spectra of $\mathrm{ZnO}$ and $\mathrm{Zn}_{\mathrm{x}} \mathrm{Fe}_{(3-x)} \mathrm{O}_{4}$.
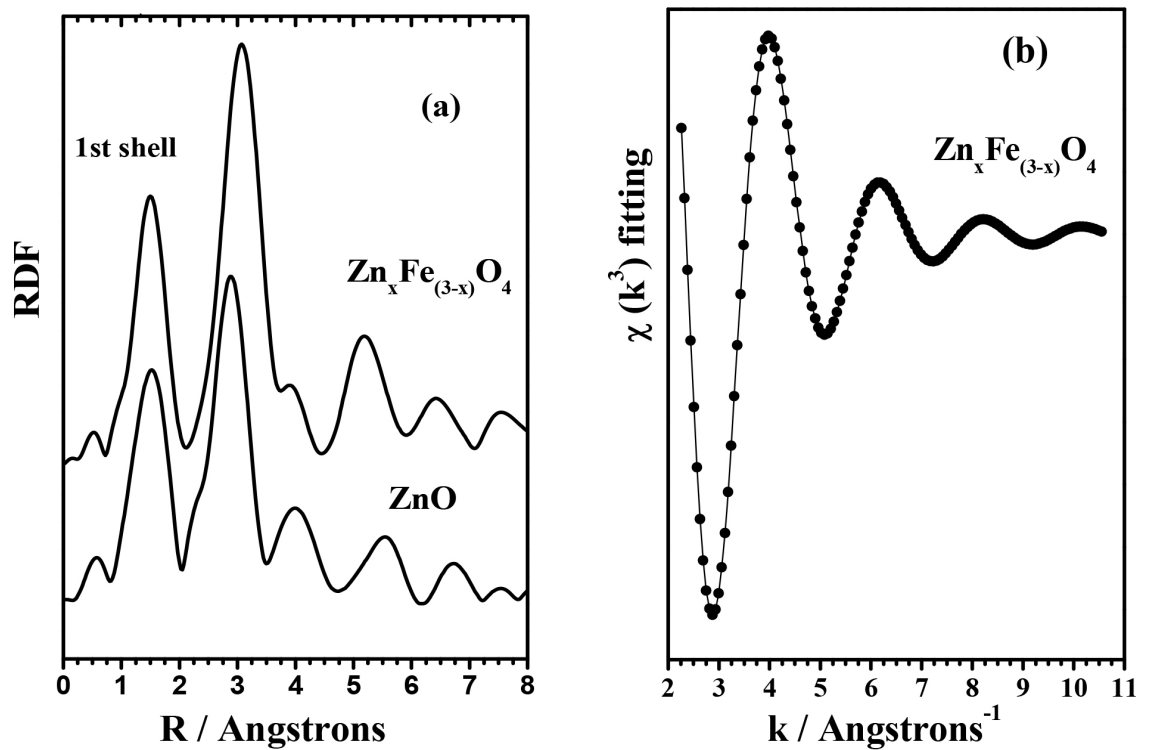

Figure 5. (a) Radial distribution function (RDF) and (b) experimental (dots) and calculated (solid line) Fourier back-transformed RDF functions obtained for the first shell of $\mathrm{Zn}_{x} \mathrm{Fe}_{(3-x)} \mathrm{O}_{4}$. 
Table 4. $\mathrm{Zn}-\mathrm{O}$ coordination distance $(\mathrm{R})$, number of oxygen atoms $(\mathrm{N})$, and Debye-Waller factor $\left(\sigma^{2}\right)$ of nonlinear fitting of filtered EXAFS spectra for the first zinc-oxygen coordination shell

\begin{tabular}{lcccc}
\hline Sample & $\mathrm{N}$ & $\mathrm{R} / \AA$ & $\sigma^{2} / \AA^{2}$ & $\Delta \mathrm{E}_{0}$ \\
\hline $\mathrm{Zn}_{\mathrm{x}} \mathrm{Fe}_{(3-\mathrm{x})} \mathrm{O}_{4}$ & 3.58 & 1.96 & $-0.0069(1)$ & -2.94 \\
\hline
\end{tabular}

The uncertainties on $\mathrm{N}$ and $\mathrm{R}$ values are $0.5 \%$ and $0.02 \AA$, respectively. $\Delta \mathrm{E}_{0}$ : energy shift.

Figure 6 shows the XANES spectra obtained for $\mathrm{Zn}_{\mathrm{x}} \mathrm{Fe}_{(3-\mathrm{x})} \mathrm{O}_{4}$ sample and $\mathrm{ZnO}$. XANES spectra of compounds containing $\mathrm{Zn}$ in tetrahedral sites present more features than those of $\mathrm{Zn}$ in tetrahedral sites. ${ }^{33}$ The energy of the first edge feature in the XANES spectrum is indicative of $\mathrm{Zn}^{\mathrm{II}}$ coordination; generally, tetrahedral edges are shifted to lower energies by $2 \mathrm{eV}$ or more compared to octahedral $\mathrm{Zn}$ edges. ${ }^{33} \mathrm{In}_{\mathrm{Zn}} \mathrm{Fe}_{(3-\mathrm{x})} \mathrm{O}_{4}$ and $\mathrm{ZnO}$ spectra, edge positions were located at 9661 and $9659 \mathrm{eV}$, respectively, indicative of $\mathrm{Zn}^{\mathrm{II}}$ occupying tetrahedral sites. The XANES spectrum of $\mathrm{Zn}_{\mathrm{x}} \mathrm{Fe}_{(3-\mathrm{x})} \mathrm{O}_{4}$ sample was very similar to that reported in previous studies ${ }^{34,35}$ for franklinite (stoichiometric $\mathrm{ZnFe}_{2} \mathrm{O}_{4}$ ), which shows two peaks after the first peak, at 9668.0 and $9671.8 \mathrm{eV}$. In the spectrum of $\mathrm{Zn}_{\mathrm{x}} \mathrm{Fe}_{(3-\mathrm{x})} \mathrm{O}_{4}$ sample these two peaks were located at 9663.0 and $9672.0 \mathrm{eV}$. Basically, $\mathrm{Zn}$ doping causes rearrangement of $\mathrm{Fe}^{\mathrm{III}}$ to tetrahedral sites.

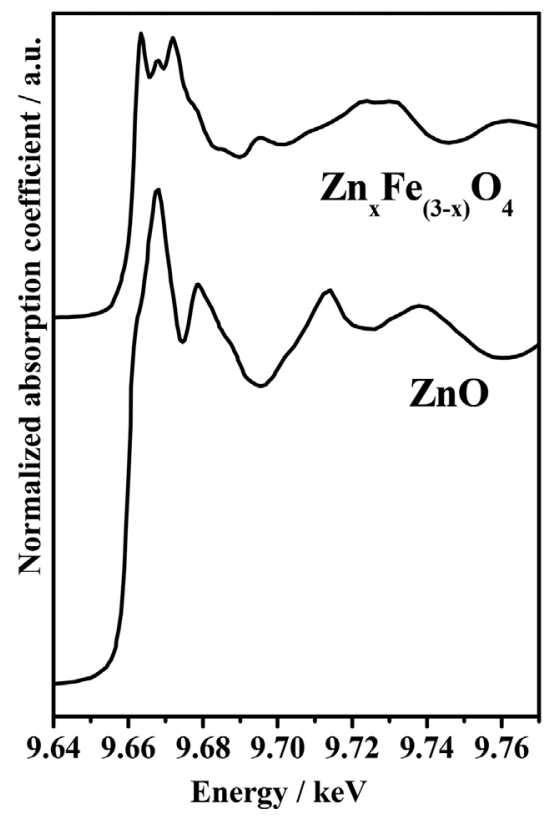

Figure 6. Normalized XANES spectra of $\mathrm{Zn}_{\mathrm{x}} \mathrm{Fe}_{(3-\mathrm{x})} \mathrm{O}_{4}$ and $\mathrm{ZnO}$.

The photocatalytic activity of $\mathrm{Zn}_{\mathrm{x}} \mathrm{Fe}_{(3-\mathrm{x})} \mathrm{O}_{4}$ towards indigo carmine degradation under UV irradiation was evidenced by a reduction in UV-Vis absorption at $610 \mathrm{~nm}$ (Figure 7a). Five experiments were carried out using an organic dye and (i) catalyst, (ii) UV light (photolysis), (iii) catalyst + UV light, (iv) catalyst $+\mathrm{H}_{2} \mathrm{O}_{2}$ solution (Fenton reaction), and $(v) \mathrm{H}_{2} \mathrm{O}_{2}$ solution $+\mathrm{UV}$ light (photoFenton reaction). The exposition of indigo carmine only to UV light (ii) or $\mathrm{ZnFe}_{2} \mathrm{O}_{4}($ i) did not result in dye degradation. Fenton (iv) and $\mathrm{H}_{2} \mathrm{O}_{2}+\mathrm{UV}$ light (v) experiments resulted in low degradation efficiencies (40\%) after $100 \mathrm{~min}$ of reaction. Compared with Fenton reaction, photo-Fenton significantly increased the degradation rate, affording a discoloration efficiency of more than $98 \%$ after $100 \mathrm{~min}$ (Figure $7 \mathrm{~b}$ ). In photo-Fenton reactions, active oxidizing species such as $\mathrm{HO}^{\circ}$ are produced in a very short time interval compared with Fenton reactions, resulting in rapid oxidation of contaminants, similar behavior was previously observed in the literature. ${ }^{11,12}$
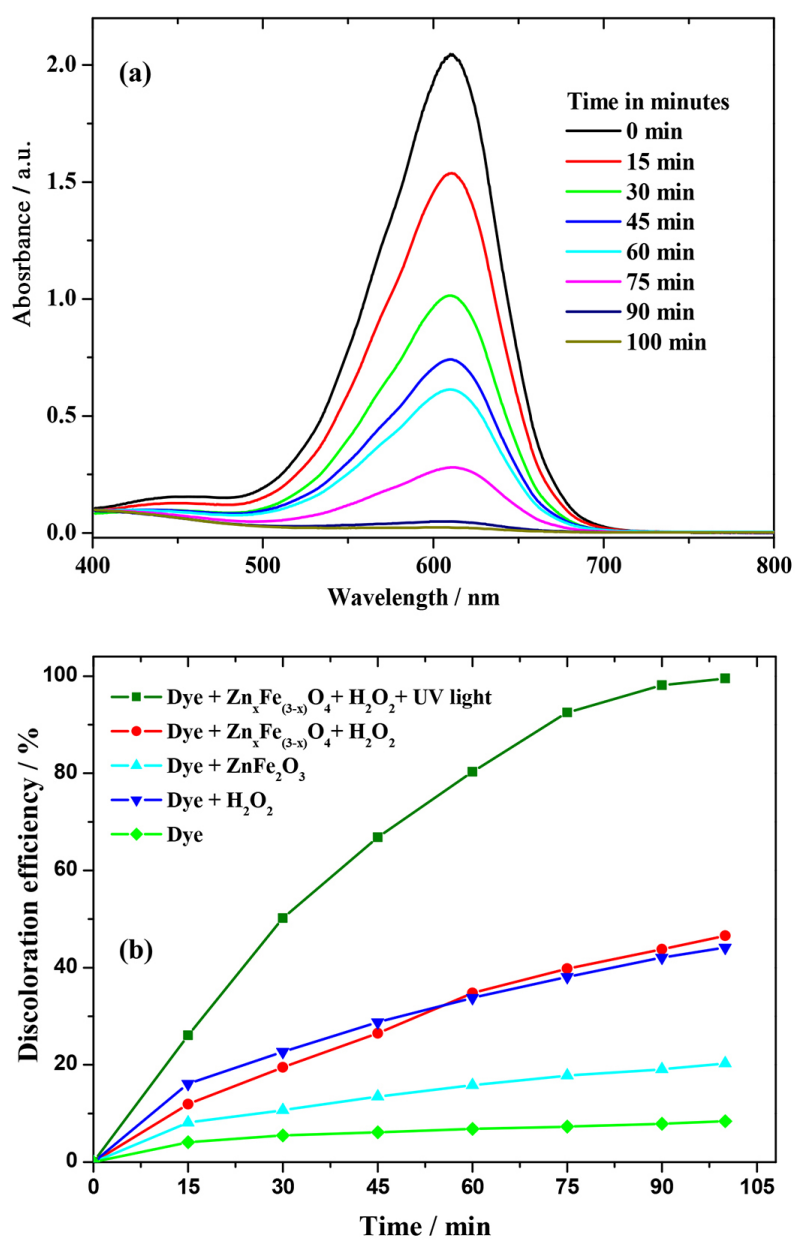

Figure 7. (a) UV-Vis spectral absorption changes of indigo carmine dye aqueous solution $\left(50 \mathrm{~mL}, 20 \mathrm{mg} \mathrm{L}^{-1}\right)$ photodegraded (experimental conditions: $\mathrm{Zn}_{\mathrm{x}} \mathrm{Fe}_{(3-\mathrm{x})} \mathrm{O}_{4}=20 \mathrm{mg}, \mathrm{H}_{2} \mathrm{O}_{2}=0.028 \mathrm{~mol} \mathrm{~L}^{-1}, \mathrm{~T}=25^{\circ} \mathrm{C}, \mathrm{pH}$ 3.0) (b) Discoloration efficiency of indigo carmine solution as a function of reaction time under different conditions.

The mechanisms of photo-Fenton oxidation reactions are well explained in the literature. ${ }^{43} \mathrm{UV}$-Vis spectra of $\mathrm{ZnFe}_{2+\mathrm{z}} \mathrm{O}_{4}$ samples exhibit intensive absorption in a wide wavelength range from UV to visible light and Šutka et al. ${ }^{16}$ 
showed that the energies of the direct band-gaps when $\mathrm{z}=0.0,0.05,0.1$ and 0.15 , vary from $2.02,1.98,1.92$ and $1.90 \mathrm{eV}$, respectively.

Figure 8 shows UV-Vis absorption bands of indigo carmine solutions before and after discoloration as a function of time. In these spectra the absorption bands below $340 \mathrm{~nm}$ are associated to the absorption of degradation products, and the bands at $280 \mathrm{~nm}$ are related to the absorption of the aromatic rings of the indigo carmine structure. According to Terres et al. ${ }^{43}$ and Giri et al ${ }^{44}$ decolorization of indigo carmine is likely to produce intermediates such as 2-amino5(sodium benzenesulfonate)-benzoic acid, anthranilic acid, benzoic acid, and aniline. These fragments present absorption bands below $340 \mathrm{~nm}$ due to the presence of an aromatic benzene ring. The spectra showed in Figure 8, display the absorption bands at $246 \mathrm{~nm}$, suggesting the formation of those afore mentioned reaction intermediates. Throughout the reaction, the intensity of these absorption bands, in the range of 300-400 $\mathrm{nm}$, decreases until completely disappears after 300 min indicating the degradation of the intermediate species. Absorption bands below $230 \mathrm{~nm}$ are associated to the residual hydrogen peroxide which absorbs in this spectral range. ${ }^{43,44}$

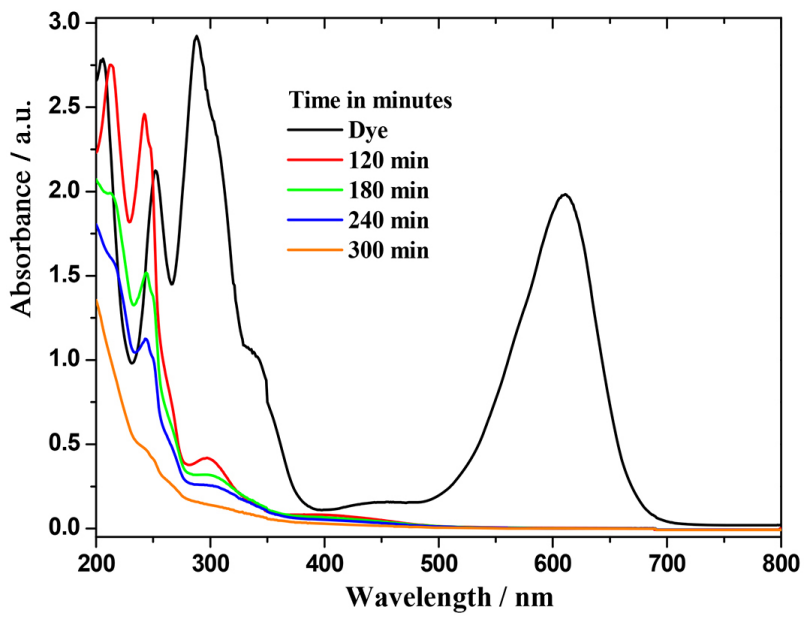

Figure 8. UV-Vis spectral absorption changes of indigo carmine solution before and after discoloration as a function of reaction time $(200-800 \mathrm{~nm}$ range shown).

\section{Conclusions}

The effect of $\mathrm{Zn}$-doping in $\mathrm{Fe}_{3} \mathrm{O}_{4}$ nanoparticles through the chemical coprecipitation route was investigated. Structural information of this Zn-ferrite was assessed by XAS, XRD and ${ }^{57} \mathrm{Fe}$ Mössbauer spectroscopy. XRD measurements indeed confirmed the formation of a cubic spinel phase, of the $F d 3 m$ space group; and it was observed that the cell dimension increase and the average crystal size decrease with $\mathrm{Zn}$-doping. ${ }^{57} \mathrm{Fe}$ Mössbauer data revealed that $\mathrm{Zn}^{\mathrm{II}}$ cations replace $\mathrm{Fe}^{\mathrm{III}}$ ions in tetrahedral sites. EXAFS results confirm that dopant $\mathrm{Zn}$ ions mainly occupy tetrahedral sites. Photo-Fenton tests showed that the use of this spinel ferrite powders showed a significant catalytic efficiency, on degrading $98 \%$ of aqueous indigo carmine after $100 \mathrm{~min}$ reaction. This zinc-doped $\mathrm{Zn}_{\mathrm{x}} \mathrm{Fe}_{(3-\mathrm{x})} \mathrm{O}_{4}$ ferrite was revealed to be highly efficient as catalyst, and it opens many more perspectives on the development of new related $\mathrm{Zn}$ ferrites prepared through different chemical routes with high photocatalytic performance in order to promote environmental remediation of wastewater of natural water bodies.

\section{Acknowledgments}

The authors thank the Brazilian Synchrotron Light Laboratory (LNLS, grant No. D04B-XAFS1 No. 4845/05) and the Espírito Santo Research Foundation (FAPES) for the financial support. JDF is indebted to Brazilian National Council for the Scientific and Technological Development (CNPq) for the research grant No. 304958/2017-4.

\section{Author Contributions}

The authors Luciana B. Biazati and Lucas Lorenzini were responsible for the investigation, data curation, formal analysis (synthesis, sample preparation and analysis); Sandra A. D. Ferreira for investigation, data curation, writing original draft and writing-review and editing; Arilza O. Porto worked in the EXAFS measurements, data analysis data curation and writing and reviewing the manuscript; Eustáquio V. R. de Castro and Marcos B. J. G. de Freitas for conceptualization and writing-review and editing; José D. Fabris worked in the Mossbauer measurements, for conceptualization and writing-review and editing; Maria de Fátima F. Lelis worked in the XRD and Mossbauer measurements, conceptualization, project administration and writingreview and editing.

\section{References}

1. Music, S. In Mössbauer Spectroscopy of Sophisticated Oxides; Vértes, A.; Homonnay, Z., eds.; Akadémiai Kiadó: Budapeste, 1997.

2. Pottker, W. E.; Ono, R.; Cobos, M. A.; Hernando, A.; Araujo, J. F. D. F.; Bruno, A. C. O.; Lourenço, S. A.; Longo, E.; Porta, F. A. L.; Ceram. Int. 2018, 44, 17290.

3. Dalawai, S. P.; Shinde, T. J.; Gadkari, A. B.; Vasambekar, P. N.; J. Solid State Electrochem. 2016, 20, 2363.

4. Bindu, K.; Sridharan, K.; Ajith, K. M.; Lim, H. N.; Nagaraja, H. S.; Electrochim. Acta 2016, 217, 139.

5. Karmakar, M.; Das, P.; Pal, M.; Mondal, B.; Majumder, S. B.; Mukherjee, K.; J. Mater. Sci. 2014, 49, 5766. 
6. Bangale, S.; Bamane, S.; Carbon: Sci. Technol. 2013, 5, 231.

7. Mukherjee, C.; Mondal, R.; Dey, S.; Kumar, S.; Das, J.; IEEE Sens. J. 2017, 17, 2662.

8. Liu, Y. L.; Liu, Z. M.; Yang, Y.; Yang, H. F.; Shen, G. L.; Yu, R. Q.; Sens. Actuators, B 2005, 107, 600.

9. Hankare, P. P.; Jadhav, S. D.; Sankpal, U. B.; Patil, R. P.; Sasikala, R.; Mulla, I. S.; J. Alloys Compd. 2009, 488, 270.

10. Rashad, M. M.; Mohamed, R. M.; Ibrahim, M. A.; Ismail, L. F. M.; Abdel-Aal, E. A.; Adv. Powder Technol. 2012, 23, 315.

11. Rocha, A. K. S.; Magnago, L. B.; Santos, J. J.; Leal, V. M.; Marins, A. A. L.; Pegoretti, V. C. B.; Ferreira, S. A. D.; Lelis, M. F. F.; Freitas, M. B. J. G.; Mater. Res. Bull. 2019, 113, 231.

12. Ferreira, S. A. D.; Donadia, J. F.; Gonçalves, G. R.; Teixeira, A. L.; Freitas, M. B. J. G.; Fernandes, A. R.; Lelis, M. F. F.; J. Environ. Chem. Eng. 2019, 7, 103144.

13. Rashdan, S. A.; Hazeem, L. J.; Arab J. Basic Appl. Sci. 2020, 27, 134.

14. Li, M.; Liu, X.; Xu, T.; Nie, Y.; Li, H.; Zhang, C.; J. Magn. Magn. Mater. 2017, 439, 228.

15. Li, F.; Wang, H.; Wang, L.; Wang, J.; J. Magn. Magn. Mater. 2007, 309, 295.

16. Šutka, A.; Pärna, R.; Kleperis, J.; Käämbre, T.; Ilona, P.; Korsaks, V.; Malnieks, K.; Grinberga, L.; Kisand, V.; Phys. Scr. 2014, 89, 044011.

17. Magnago, L. B.; Rocha, A. K. S.; Pegoretti, V. C. B.; Ferreira, S. A. D.; Lelis, M. F. F.; Freitas, M. B. J. G.; Ionics 2018, 25, 2361.

18. Morais, V. S.; Barrada, R. V.; Moura, M. N.; Almeida, J. R.; Moreira, T. F. M.; Gonçalves, G. R.; Ferreira, S. A. D.; Lelis, M. F. F.; Freitas, M. B. J. G.; J. Environ. Chem. Eng. 2020, 8, 103716.

19. Amiri, M.; Salavati-Niasari, M.; Akbari, A.; Gholami, T.; Int J. Hydrogen Energy 2017, 42, 24846.

20. Lima, E. S.; Costa, L. S.; Sampaio, G. R. L. M.; Oliveira, E. S.; Silva, E. B.; Nascimento, H. O.; Nascimento, R. F.; Moura, K. O.; Basto-Neto, M.; Loiola, A. R.; Sasaki, J. M.; J. Braz. Chem. Soc. 2019, 30, 882.

21. Martins, M. L.; Florentino, A. O.; Cavalheiro, A. A.; Silva, R. I. V.; Santos, D. I.; Saeki, M. J.; Ceram. Int. 2014, 40, 16023.

22. Shahraki, R. R.; Ebrahim, S. A. S.; Masoudpanah, S. M.; J. Supercond. Novel Magn. 2015, 28, 2143.

23. Kefeni, K. K.; Msagati, T. A. M.; Mamba, B. B.; Mater. Sci. Eng., B 2017, 215, 37.

24. Sun, Y.; Wang, W.; Zhang, L.; Sun, S.; Gao, E.; Mater. Lett. 2013, 98, 124.
25. Nan, C.; Fan, G.; Fan, J.; Li, F.; Mater. Lett. 2013, 106, 5.

26. Wu, J.; Pu, W.; Yang, C.; Zhang, M.; Zhang, J.; J. Environ. Sci. 2013, 25, 801.

27. Mahnaz, A.; Salavati-Niasari, M.; Akbari, A.; Adv. Colloid Interface Sci. 2019, 265, 29.

28. Priyanka, S.; Rupali, R.; Kalyan, M.; J. Magn. Magn. Mater. 2019, 475, 130.

29. Oh, Y.; Moorthy, M. S.; Manivasagan, P.; Bharathiraja, S.; Oh, J.; Biochimie 2017, 133, 7.

30. Abreu Filho, P. P.; Pinheiro, E. A.; Galembeck, F.; Labaki, L. C.; React. Solids 1987, 3, 241.

31. Jeffery, P. G.; Hutchison, D.; Chemical Methods of Rock Analysis, $3^{\text {rd }}$ ed.; Pergamon Press: Oxford and New York, 1981.

32. Brand, R. A.; Normos-90 Laboratoriumfür Angewandte Physik; Universität Duisburg: Duisburg, Germany, 1999.

33. Ressler, T. J.; J. Synchrotron Radiat. 1998, 5, 118.

34. Mineral Powder Diffraction File-Data Book; JCPDS, International Center Diffraction Data: USA, 1980.

35. Holland, T. J. B.; Redfern, S. A. T.; Mineral. Mag. 1997, 65, 61.

36. Cullity, B. D.; Elements of X-ray Diffraction, $2^{\text {nd }}$ ed.; AddisonWesley: London, 1978.

37. Kaye, G. W. C.; Laby, T. H.; Table of Physical and Chemical Constants (and Physical and Chemical Functions); Longman: London and New York, 1973.

38. Maiti, D.; Saha, A.; Devi, P. S.; Phys. Chem. Chem. Phys. 2016, 18,1439

39. Sawatzky, G. A.; Van der Woude, F.; Morrish, A. H.; Phys. Rev. J. Arch. 1969, 187, 747.

40. Sawatzky, G. A.; Van der Woude, F.; Morrish, A. H.; Phys. Rev. J. Arch. 1969, 183, 383.

41. Costa, A. C. S.; Souza Jr., I. G.; Batista, M. A.; Silva, K. L.; Bellini, J. V.; Paesano Jr., A.; Hyperfine Interact. 2007, 175, 103.

42. Costa, A. C. S.; Souza Jr., I. G.; Batista, M. A.; Lopes, D. A.; Silva, K. L.; Bellini, J. V.; Paesano Jr., A.; Hyperfine Interact. 2007, 176, 107.

43. Terres, J.; Battisti, R.; Andreaus, J.; Jesus, P. C.; Biocatal. Biotransform. 2014, 32, 64.

44. Giri, R. R.; Ozaki, H.; Takayanagi, Y.; Taniguchi, S.; Takanami, R.; Int. J. Environ. Sci. Technol. 2011, 8, 19.

Submitted: May 19, 2021

Published online: September 16, 2021 